TITLE:

\title{
Myoglobin gene expression attenuates hepatic ischemia reperfusion injury(Abstract_要旨)
}

$\operatorname{AUTHOR}(\mathrm{S}):$

Nitta, Takashi

\section{CITATION:}

Nitta, Takashi. Myoglobin gene expression attenuates hepatic ischemia reperfusion injury. 京都大学, 2003, 博士(医学)

ISSUE DATE:

2003-03-24

URL:

http://hdl.handle.net/2433/148743

RIGHT: 
氏名新苗等主

学位(専攻分野) 博士（医学）

学位記番号医 博 第 2620 号

学位授与の日付平成 15 年 3 月 24 日

学位授与の要件 学位規則第 4 条第 1 項該当

研究科. 専攻医学研究科外科系專攻

学位論文題目 Myoglobin Gene Expression Attenuates Hepatic Ischemia Reperfusion Injury

(ミオグロビン遺伝子発現による肝虚血再灌流障害改善効果の研究)

論文調査委員教授 千葉勉教授田中絋一教授山岡義生

論文 内 容 の 要旨

【目的】肝臓の低酸素や虚血・再灌流による障害では, 肝細胞のミトコンドリア障害によりATPレベルが低下する。ミ オグロビンは心筋や骨格筋中で酸素のリザーバーとしてミトコンドリアへの酸素拡散を促進させ, 酸化的リン酸化能をえ進 させる働きがある。そこで, 肝臟には存在しないミオグロビン遺伝子を肝細胞に導入し, 肝虚血再灌流障害に対する効果を 期待し以下の実験を行った。

【方法と結果】ヒトミオグロビン遺伝子を含むアデノウイルスベクター（AdCMVMyo）及びコントロールアデノウイル スベクター (AdCMVLacZ) を, Hep3B 細胞（MOI20-100）及び C57BL/6 マウス（1X $\left.10^{9} \mathrm{pfu}\right), \mathrm{SD}$ ラット（5X109pfu） に投与し，以下の実験を行った。

1 ）AdCMVMyo 感染後のミオグロビン発現を明らかにするために, Hep3Bに MOI50にて AdCMVMyoを感染させ, ミ オグロビン mRNA 及び蛋白の発現をそれぞれ RT-PCR 及び免疫染色で確認した。SDラットにおいてもWestern blot 及び免疫組織染色にて myoglobinの蛋白発現を確認した。

2 ) ミオグロビン発現のミトコンドリア機能に対する効果を明らかにするために細胞内 ATP 量を HPLCにて検討した。

AdCMVMyo 感染72時間後の Hep3B (26.1 $\left.\pm 1.1 \mathrm{nmol} / 10^{6} \mathrm{cells}\right)$ および C57BL $/ 6$ マウス肝組織 $(4.19 \pm 0.2 \mu \mathrm{mol} / \mathrm{g}$ wet liver )では未感染群 $\left(22.9 \pm 1.9 \mathrm{nmol} / 10^{6}\right.$ cells, $3.11 \pm 0.20 \mu \mathrm{mol} / \mathrm{g}$ wet liver $) に$ に比し，有意にATPが高值とな つた。

3 ）発現ミオグロビンの酸素結合能を明らかにするために分光光度計を用いて差スペクトラムを比較した。AdCMVMyo 感染 Hep3B を酸素化, 脱酸素化し得られた差スペクトラムは, 精製ミオグロビン及びマウス筋肉より得られた差スペ クトラムに近似した 2 峰性のスペクトルであったことより導入ミオグロビン蛋白はへム蛋白として機能していると考え られた。

4) 肝虚血再灌流障害に対するミオグロビン発現の効果をSD ラットの20分の全肝虚血モデルにて検討した。AdCMVMyo 群では無処置群及び LacZ 遺伝子導入群に比し, 再灌流後180分の血清, AST, ALT, LDH の有意な改善効果が認め られた。HE 染色による組織学的検討では, 無処置群及び $\mathrm{LacZ}$ 遺伝子導入群における肝組織内の中心静脈周囲のうっ 血・壊死が，ミオグロビン遺伝子導入群では認められなかった。更にミオグロビン発現の肝虚血再灌流障害抑制メカニ ズムを明らかにするためにラジカルによる蛋白変性の指標としてカルボニル化蛋白を oxyblotにて検出した。無処置群 に比べミオグロビン遺伝子導入群で蛋白変性の減少を認めたことより, 酸化ストレスの軽減が肝虚血再灌流障害抑制メ カニズムのひとつと考えられた。

【結論】アデノウイルスベクターによるミオグロビンの遺伝子導入は，酸素結合能及び ATP 量の克進を介して，ラット 肝虚血再灌流障害を抑制した。酸素及びATP リザーバーの肝臓への導入は，肝臓外科に扔ける肝障害抑制の新たな手段と なる可能性が示された。 


\section{論 文 審 査 の 結 果 の 要 旨}

本研究は, ミオグロビン遺伝子を, 本来その発現のみられない肝臓に導入し, 酸素・ATPのリザーバーとして肝虚血再 灌流障害改善に寄与するかを，発現したミオグロビンの酸素結合能および細胞内 ATP 産生艺進効果，血清学的，組織学的 改善効果から検討されたものである。

本研究では，ヒトミオグロビン遺伝子を含むアデノウイルスベクター（Adeno-Myo）を遺伝子導入発現ベクターとして 用いた。コントロールには，ウイルス非投与群，及び $\beta$-galactosidase 発現アデノウイルスベクター（Adeno-LacZ）を用 いた。

(1) Hep3B 細胞に Adeno-Myo 感染を起こさせると，ミオグロビンの発現及び酸素結合能，ATP 産生艺進効果を示した。 (2)マウスの尾静脈よりAdeno-Myo を投与すると，肝細胞にATP 産生立進を認めた。さらに，ラットの20分全肝虚血モ デルでは，Adeno-Myo 投与群における再灌流後180分の血漿逸脱酵素に有意な改善効果を認め，組織学的には，コントロ ール群に㧍いて，中心静脈周囲のうっ血・壞死が著明であったが，Adeno-Myo 投与群では認められなかった。酸素・ ATP リザーバーの肝蔵への導入は，肝臓外科に㧍ける肝障害抑制の新たな手段となる可能性が示された。

以上の研究は肝臓における肝虚血再灌流障害の機序の解明に貢献し，肝蔵外科手術領域の臨床応用に寄与するところが大 きい。

したがって，本論文は博士 (医学) の学位論文として価值あるものと認める。

なお，本学位授与申請者は，平成15年 2 月 27 日実施の論文内容とそれに関連した試問を受け，合格したものと認められた ものである。 